EDITORIAL

\title{
Ampliando o alcance: mídia eletrônica e língua estrangeira
}

Planos e projetos da $R B M E$ vêm sendo concretizados continuamente. A partir deste número, passamos a publicar também um resumo em espanhol e uma versão completa em inglês de cada um dos artigos. Nossa intenção é ampliar o universo de leitores e expandir o espectro de contribuições, fortalecendo nosso pleito de indexação em banco de dados bibliográficos mais abrangentes. A conseqüência concreta deste processo deverá ser o aumento do impacto das nossas publicações produzindo maior influência no desenvolvimento do corpo de conhecimento em medicina e ciências do exercício.

Simultaneamente, estamos disponibilizando o acesso ao conteúdo da $R B M E$ via internet no endereço www.rbme.org.br. Encontram-se na página os artigos publicados, editoriais, expediente com dados técnicos do periódico e regras para autores. Números anteriores serão progressivamente acrescentados até que todo o acervo da $R B M E$ esteja disponível em meio eletrônico. No momento, todo o conteúdo pode ser acessado sem custos e os artigos captados no formato pdf. Desde o dia 17 de fevereiro, quando inauguramos o site, estamos mantendo mais de 100 visitas por dia. A experiência internacional mostra que a disponibilidade on-line dos artigos de um periódico científico estimula as assinaturas em papel, o que esperamos que ocorra também com a RBME.

Planejamos com a implementação destas ações aproveitar o melhor dos dois mundos, ou seja, atrair leitores de língua inglesa sem abrir mão do nosso idioma e disponibilizar o acesso eletrônico sem deixar de publicar impresso. Contamos com todos vocês leitores, autores, revisores e anunciantes para catalisar a expansão da $R B M E$.

Prof. Dr. Antonio Claudio Lucas da Nóbrega

Editor-chefe 